\title{
Tianheng Sea Sacrifice Festival: The Chinese-Style Carnival
}

\author{
Hongjuan Zhao \\ Qingdao University of Science and Technology
}

\begin{abstract}
The Sea Sacrifice Festival in Tianheng town, Qingdao, China starts from Ming dynasty and enjoys a history of more than 500 years. As the largest and most famous festival of offering sacrifice to the sea in China, it develops from the traditional ritual performed by fishermen, who intended to pray for blessing and safety from the God of the Sea into a huge carnival attending by thousands of people to express their aspiration for a wonderful life and bright future. This day, the sea sacrifice festival has the new social values and cultural connotations due to the change of life style, the rise of intangible cultural heritage protection activities, and the integration of many other culture elements, such as Yanko, drum, and Peking opera performance.
\end{abstract}

Keywords: Tianheng sea sacrifice festival, ritual, sea gods, carnival

\section{Brief Introduction of Tianheng Sea Sacrifice Festival}

Tianheng sea sacrifice festival is the largest ceremony of offering sacrifices to the sea in the northern part of China, which has lasted for more than 500 years (Tianheng Compilation Committee, 2008, 211). This festival is a marine culture carnival with Chinese characteristics, which is people want to get rid of the pressure of hard work and life dilemmas to pray to the gods for harvest and happiness in the emotion. In Tianheng area, the ritual of offering sacrifice to the sea gods is carried out around the sixth solar term Grain Rain, which means "Guyu" in Chinese calendar, in the middle of March every year because that's the time of fish harvest. The fisheries production is influenced by the time and weather strongly, so in the beginning of the new production season, the corresponding ritual activities will be held by fishermen to pray for the safety and harvest. In Tianheng area, there is an old saying that during Guyu season hundreds of fish will be ashore.

Tianheng Festival is a sacrificial activity in the background of marine belief, however, it is a kind of folk custom rather than solemn religious ceremonies, and the ritual is a local customs show. Sea sacrifice initially originates from fishermen's fear and ignorance to the natural phenomenon, and hopes to get the blessing from Dragon king, the Heavenly Master, Matsu, Sun Xiangu (a woman gives help to fisherman in legend) and the fourth Lord (he who evolved from a fox who can be in charge of the sea world to quell the shipwreck so that fishermen can return safely with rich harvest). Later, the fishermen in Tianheng town also make sacrifice to pray for their ancestors and other fishermen who died during in the sea, and to express the appreciation and gratitude of living ones to their ancestors and they also hope the soul of the dead can find a peace land. However, in later, with the development of civilization and culture, fishermen have turned the sea sacrifice from the natural worship which comes from the ignorance and fear into the purposive worship for a better and peaceful life.

Hongjuan Zhao, Lecturer, Foreign Languages School, Qingdao University of Science and Technology, China; main research field: Folklore, Cross Culture Communication.

This article is funded by Social Science Association of Shandong Province: A pictorial illustration of Qilu folk culture (2014). 
In Tianheng area, fishermen's belief for the local gods is for the efficacy and comfort of the heart, but not the pursuit of the source properties of the gods, so "a person may worship a lot of gods at the same time. He can visit the Buddhist temple in the morning, Taoist temple in the afternoon, and does not feel confused" (Zhang 2007). In fact, from the fear for the sea and nature phenomenon to purposive worship for the sea gods reflects the utilitarian nature of the marine belief which means the belief is out of some practical and realistic purposes (Qu 1999, 167). As Malinowski put it, humans have a relatively stable control over the forces of natural fertility in order to balance and conform to the close relationship between man and the surroundings, and to celebrate this close relationship with ritual ceremonies (1960).

The procedure of Tianheng sea sacrifice is preparing the sacrifices including meat, fish, and steamed buns, writing peaceful instruments, decorating Dragon King Temple and banqueting friends and relatives. Every year ten days before the festival, the women of Tianheng town begin to make the steamed buns with different shapes such as peach, holy worms, bucket, and others. Each steamed bun weighs about five ponds and decorated by different patterns that include two lions play the ball, magpie sing in the three, flowers of every kind are in bloom and so on, and all of these patterns show the wishes of fishermen for the happy and rich life. Near the sea festival day, men are busy preparing three sacrifices: pigs, chickens, and fish. There are some special reasons to offer these three sacrifices during the festival, for pigs, as the fishermen will stay in the boat for several months if they go fishing on the sea, pork was the cherishing things and hard to obtain for them; as for chickens, in Chinese phonetics, the pronunciation of chicken is completely as the word propitious, both of them mean luck; the reason to sacrifice the fish is so obvious which means fishermen long for the harvest of fishes. In the past, after the sacrifice ceremony, the offerings would be thrown into the sea as the fishermen thought the gods in the sea would protect them if they got the offerings. However, in recent years, the practice of throwing offerings has been canceled, mainly due to marine conservation and development. However, other rituals, such as writing and firing the "peace document" which is written by the most respected old men, dressing new clothes, placing the fish boats in front of Dragon king temple, throwing candy into the set off firecrackers are preserved until now from Ming dynasty, 500 years before. On the day of the festival, all the fishermen are immersed in a pious, mysterious, and joyful atmosphere, the lively scene is better than the New Year. It is noon after various ceremonies ended, the fishermen will share the sacrifice offerings to their relative who don't do fishing, while they also prepare a big feast for the friends and relatives.

For the fishermen, the Festival is the people's emotional expression for the happy life and bright future in the soul, and it is also a manifestation of cohesion and unity of the whole community; for the governors in the old times or government in nowadays, the festival is conducive to people's rally and unity, which makes the premise and basis for the stability of the society and economic development, so the festival gets the support from common people and the government, which is why it lasts for so long time.

\section{The Construction of the Marine Belief System in Tianheng}

The life in the coastal area is different from the land, which is greatly influenced by forces such as climate, sea breeze, and other natural forces, so the fisheries production is unpredictable and unstable. In this precarious situation, fishermen's need for peace and harmony is extremely urgent, and this mentality makes them more dependent on the will of faith. In order to achieve the survival of peace, fishermen will put the soul in the gods to pray for peace and happiness, which are the prerequisites and conditions for the marine worship and sacrifice. 
In Tianheng marine belief system, the main god of worship is the Dragon King. According to Buddhism, Dragon King can make rain for the drought places, and in the inland areas of China, there is a folklore custom of praying for rain from the Dragon King as he has the function of managing the water. While in the coastal areas, fishermen think the Dragon King must be a powerful god who can manage the sea, so the Dragon King becomes the most important god in the seaside places. 18 out of 30 villages in the Tianheng town are fishing villages, each fishing village has a Dragon King Temple. The time that go to worship in the Dragon King temple are determinate, mainly on the sea sacrifice festival day, the Dragon King's birthday, and the Spring Festival.

During the festival, on the altar of offering sacrifices to the sea, the God of Wealth who is also known as the Lord God is worshiped. The Lord God is an important god of the Chinese people's folk beliefs and the god doesn't belong to Buddhism, a Taoism or other religions. A belief in the Lord God is not the construction of the god of personality, as the Lord God has no specific image and his function is to let the fishermen get a good harvest. In addition, as South China has a belief in the customs of Matsu goddess, with the exchange of Chinese culture and economy in the north and south part, Matsu goddess has become an important god in the north part of China, especially in Tianheng area.

Besides the Dragon King, the Lord God, and Matsu goddess, another two gods that Tianheng people worshiped are derived from the legends. The most popular legend is about Sun Xiangu, who is a clever, helpful and warm hearted girl. However, Sun girl died before she get married, and in the year she died she appeared in the dream of a boat owner to tell him he and his crew will meet the shipwreck and they should follow her suggestions to avoid this disaster. The next day the boat owner changed his former route and followed the way the girl told him; it's unbelievable that there was a hurricane in the former direction and all of them avoided that way and were saved. Later in order to show thanks to the girls, the boat owner according to the memory in his dream went to the girl's hometown and found the village really had a girl appeared in his dream whose surname is Sun. The boat owner and the villagers think Sun girl must be a goddess having power to help and protect fishermen, and she should be respected. From then on, they called the Sun girl Sun Xiangu which means a goddess whose surname is Sun. Sun Xiangu is a so important deity in local places, which may be second only to the Dragon King, even though she didn't have her own temple for people to worship.

In addition, Tianheng people also believe in fox deity. In China, fox faith began in the Tang Dynasty (618-907 A.D.); people think that fox is a blessing animal. The fox belief is very popular in northern China reflecting the animal worship in agricultural community and on the basis of this belief, a variety of myths and legends are produced. According to the legend in Tianheng area, a deity whose name is fourth Lord is a fox, who often helped fishermen to avoid the shipwreck and bring luck for local people. According to the local villagers, there is a cave in Tianheng town and this cave is the place where the Fourth Lord cultivated and lived. After the middle of the 20th century, due to the eradication of superstition activities, fox worship customs gradually disappeared in many places of China. However, during Tianheng sea sacrifice festival, Tianheng people still worship the fox deity, the Fourth Lord for the peace.

In fact, the sea god worship is the imagination of the coastal people according to their work and life, and the belief of the Dragon King may be the origin of other legends such as Sun Xiangu, the Fourth Lord and so on, and then formed a complete marine belief spectrum, with the gods of myth and legend in coastal carrier.

The gods worshiped by the fishermen are the worship of alien force, that is, the worship of supernatural and super-social forces in the course of human development and exploitation to the oceans. In the 
above-mentioned marine belief system, the gods such as the Dragon King and Mazu Goddess are the Almighty God, can not only bring peaceful life for people, but also get rid of disaster, as well as having the function of curing diseases. In addition, the beliefs of costal people promote the cohesion of the community which can be manifested through ritual ceremonies. These ritual ceremonies are functional to connect all people together, to promote and develop the sharing and similar cultural heritage in the community, and to help them find common things in thoughts, emotions, and behaviors which are contributing to social cohesion. As a result of this, it is natural that the marine belief and faith evolved into a corresponding ritual gradually, as Taylor held that religious rituals are both symbolic and practical, and their forms are repeated until the underlying meaning changes (2010).

\section{The Developing and Changing of Tianheng Sea Sacrifice Festival}

Regardless of in ancient or modern times, religion is made up of parts, it is a more or less complex system of myths, dogmas rites, and ceremonies (Durkheim 1964, 36). The festival is an integral part of human culture, and also the product of the development of local populations to adapt to the development of the environment. The festival, developing from relatively closed situation to open one, provides a window to observe the culture of a nation and a key to study the regional culture. Exploring the development process of Tianheng sea sacrifice festival can show the change of the local culture, custom, and lifestyle. The development process of this festival is from the initial spontaneous faith and belief, to the collective small-scale ritual, and now the government builds a large scale carnival.

\subsection{The Period Personal Belief}

In the period of personal belief, it's just the believers devoted to the sacrifices and reverence to the gods, such as the Dragon King, Sun Xiangu, the Four Lord, the Heavenly Master, and the Matsu. The initial ceremonies were mainly held by households, and only young adults, but not women and children can participate. There are two main reasons for why women and children are forbidden to participate in the festival: One is the influence of the traditional thinking of male superiority and female inferiority; the other is out of the love for women and children, as the face of Dragon King is fierce, in order not to frighten women and children by preventing their participation in the activities of the sacrifice to the Dragon King. The worship time in this period is generally before and after the Guyu, but there is no uniform time, as long as they finished the worship ritual for the Dragon King, Xiangu, and other gods, fixed the boat and fishing net, and added fishing gears to make good preparation for the production. The sea sacrifice festival is also called net-preparation.

\subsection{The Period the Collective Worship}

From the beginning of the 20th century, with the development of fishery production, fishermen began to go fishing in a group by the same surname family or a few small-scale combination of several families, the marine sacrifice thus became a small scale ritual activity, no longer single-handedly by the family. In the 1960s, sea sacrifice rituals were terminated for some reasons. Since 1980, the sacrifice ritual rose gradually in Tianheng area. In 1987, Zhou Gezhuang village in Tianheng town made an "Assembled fishery ritual" to celebrate the festival together, namely, in some group but not by single family. In 1996, the village committee made sure the festival time on March 18 each year. 


\subsection{The Period of Government Participation}

Brown once mentioned that faith is manifested, for the most part, in ritual and practical use (Brown 2007, 335). In order to protect, develop, and inherit the sea sacrifice ritual, and to make use of such rituals to promote economy and culture development, the local government hopes Tianheng sea sacrifice festival to become the largest ceremony with most abundant historical elements and folk tourism activities in the northern coastal area of China. In 2004, Tianheng sea sacrifice Festival changed its name to "Tianheng Sea Folk Culture Festival," and the festival time changed from one day on the March 18 into three days around the weekend on March 18. With the infiltration of various economic elements, Tianheng sea sacrifice festival is no longer a simple marine festival in the past, but as a marine tourism and cultural feast, the government hopes to use the rich marine resources and traditional folkways to develop tourism, promote economic development, and increase people's income. After involving in the sea festival, the government not only reserves the traditional worship for five deities but also adds more activities and performances in it, such as the Peking Opera, lion dance, Yangge dance, bean dancing, and gets rid of evil exorcism dance as well as a variety of other art performances, large-scale show and exhibitions. In addition, the local government develops a variety of markets to sell all kinds of seafood and handicrafts. As more and more people know the Festival, it not only promotes the sale of steamed buns, but also lets its making skills be inherited. Moreover, with the expansion of ritual activities, local dining, tourism and other industries have developed gradually. In addition, government puts many local historical figures and historical events into the ritual activities that make a more profound understanding and appreciating for their own culture and hometown.

In short, the festival now is deepening and enriching the connotation of the festival, not only makes local people appreciate the holiness and solemn marine belief rituals, but also attracts visitors to appreciate the significance of this festival. In a word, because of government involvement, a plain and simple sea gods worship gradually evolved into a Chinese style carnival festival with diversified activates and performance.

The simple sea gods belief has become a local special marine carnival, what is the cultural and social meaning of this carnival? Every nation should respect for and protection of multi-cultural and pluralistic beliefs, in line with the law of historical development, but when the government activities involved too much into fishermen's festival, the taste of traditional folk will change? In the next part, we will elaborate on these issues.

\section{Modern Sense of Tianheng Sea Sacrifice Festival-A Chinese-Style Carnival}

Each belief has a specific sacrificial ritual, procedures, and places which are exceptionally solemn and sacred. It is believed that, the bridge between man and God can be built and the communication can be achieved through the completion of the ritual ceremony. As the mortal world has increased the authority by means of the power of gods, so all the spiritual beliefs attach great importance to rituals.

Tianheng sea sacrifice Festival developed from the simple ritual of sea gods' worship to a grand festival with rich connotation, which is full of yearning for life and longing for bright future. Nowadays, Tianheng sea sacrifice Festival is not the original sacrificial ritual with superstition and it has gradually evolved into a kind of custom and culture activity of coastal fishermen in Tianheng area, which has been affirmed by the government and society. Tianheng Festival is a sacred experience developed from single family and community rituals. The expressions of personal faith and personal piety in early days, and the initial function of offering sacrifices to the sea to seek for safety and harvest continue to this day. With the arrival of reform and opening up, the local 
economy has been developing vigorously and the function of festival has been changing gradually. Tianheng Festival can not only provide spiritual belief for the local society, but also provide a mechanism of organization and integration for social solidarity, which showed a cohesive function. In the new century, the local production mode and life style have changed greatly, and the function of culture, economy, entertainment, and community communication has been highlighted. The sacrificial rituals were passed through their cultural language and sacrificial rituals, and the common rituals strengthened moral consciousness and social integration.

In the atmosphere of the festive carnival, the sea sacrifice festival has the power to incite the feelings of fishermen together to form a whole. With the infection of this powerful atmosphere, fishermen will have the common cognitive and emotional input and continue to extend the identity. In the past, fishermen seldom participate in public affairs as they have strong herd mentality and psychological dependence. In recent years, the traditional clan management models have been weakening, as for a long time, fishermen just devote to the fishery production and don't have a deep understanding for the grass-roots democracy, much less to attending the corresponding activities. Sea sacrifice festival changed the fishermen's attitude to attending the public affairs, and it made them feel they can be one part of the public affair and have the rights to participate some public activities. The fishermen's sense of democracy and consciousness of participation have been enhanced by the practice of festival activities, which will establish a good sense of citizenship. During this period, in preparation for the sea festival, the fishermen in local places assembled several organizations voluntarily. Although these organizations do not have clear rules and regulations and just formed due to the sea sacrifice festival, however, they can improve the level of autonomy of fishermen and local political culture in local place.

In 2016, the total number of visitors to Tianheng sea sacrifice festival was up to one hundred thousand. However, this festival is a kind of performance in line with the development of tourism in essence, and has lost some meaning of marine belief. The government decided to dig the cultural treasures of the festival, however, there has been a tendency to do big. Many fishermen think the government-sponsored activities of the festival are a little bit empty, lost the soul of worship and revere. In fact, the government does not need the power of gods to make the management, and to obtain economic interests may become a fundamental belief in local development. Religious beliefs and practices in the course of its development, have formed a long chain of economic interests. As long as economic development is conducive to growth in local revenues, all private religious beliefs and practices can be found in the development of tourism under the premise of recovery to obtain legal status. From this point of view, government cannot involve too much into fishermen festival, as the festival is the important time of fishermen who can get psychological comfort, spiritual sustenance, and the courage to overcome difficult from the celebration of the festival. Marine folk culture is the life culture that is created and inherited by common, and as the best time of local folk culture and art, the festivals constitute the important factor of grass-roots culture, and the cultural charm of the lively stage.

The government's involvement always has two different functions: On one side, the government can bring a lot of resources and money which let Tianheng sea sacrifice festival become a grand carnival to force the development of economy and improve the life of fishermen. On other side, it is the too much involvement of the government changed the festival's own form for development, the operation of the market changed the meaning of the festival in some sense. However, it can be seen that the government proposed the principle of festival celebration, that is one year and one festival, three years a bi celebration and return the festival to the fishermen which shows the government's respect for the law of folklore development. The villagers who have 
certain social influence formed a secular civil society organization, folk forces in the festival held are playing an increasingly important role. With the continuous development of the local society and the excavation of the cultural elements of the festival, Tianheng, the hero of Tianheng town, its loyal spirits will become the trend of the spiritual and cultural life of the society. Besides, the well-off local villagers will also merge the charity with the festival so as to enrich the content of Tianheng sea sacrifice festival continuously.

\section{Conclusion}

The existence of sea gods belief and sea sacrifice ritual provides the survival space and development carrier for the inheritance of folk culture and art, and it is the support for the development of various art forms. As a regional celebration, the sea sacrifice festival is a public gathering to pray for the rich and safe life, and through a series of recreational activities to express the natural feelings. Nowadays, the festival ceremony can be described as community entertainment, local fishermen through this festival not only express their reverence to sea gods, but also release them from the hard work and tense life to get liberation of, at the same time, foreign tourists can also appreciate a cultural feast in Tianheng town. In order to protect the tradition and promote the economic development, the government gave the traditional culture the modernized content. In the end, it can come to the conclusion that Tianheng sea sacrifice festival is a kind of traditional Chinese-style carnival with some modernized atmosphere and functions.

\section{Works Cited}

Brown, A. R. R. Structure and Function in Primitive Society. Trans. Ding, G. Y. Beijng: Jiuzhou Press, 2007.

Durkheim, Emile. Trans. Joseph, W. S. The Elementary Forms of the Religious Life. London: George Allen \& Unwin LTD., 1964.

Gao, W. Research on Belief and Custom of Wenchang. Chengdu: Sichuan Press, 2008.

Historical Records Compilation Committee of Tianheng Town. Shandong: Shandong Map Press, 2008.

Malinowski, B. K. A Scientific Theory of Culture and Other Essays. New York: Oxford University Press, 1960.

Qu, Jinliang. Introduction to Marine Culture. Qingdao: Ocean University of China Press, 1999.

Tylor, E. B. Primitive Culture. London: Cambridge University Press, 2007.

Zhang, Yonghua. “On Cultural Motivation of Pluralistic Belief in China.” Journal of Sichuan Nationalities Institute 2 (2010): 53. 